\author{
格内敏** 長谷川素由** 石 尾 博 明***
}

Analysis of Deformation on an Asperity Model of Surface Roughness

by Holographic Interferometry

Satoshi KAKUNAI Motoyoshi HASEGAWA and Hiroaki ISHIO

\begin{abstract}
Measurement of temporal deformation on an asperity model of surface roughness subjected to pressure by flat punch is performed and the deformation behavior is discussed. The method is based on the minute and continuous observation of the deformation of the asperity by multiple aperture holographic interferometry, which repeats of holographic double exposures through small apertures of a mask placed in front of single holographic plate. Industrial aluminum is selected as the material of the specimens. The shape of the asperity is cone type and the asperity angle is $120^{\circ}, 154^{\circ}$ and $171^{\circ}$.

Key words: holographic interferometry, asperity model, surface roughness, flat punch, deformation behavior
\end{abstract}

1.はじめに

金属の钽視的表面突起の押しつふし遇程の解明は， 加工製品の表面仕上げ，機械要素の摩摖摩耗，圧接技 術などの基碟として極めて重要であり, 多方面から多 くの研究がなれてきだ〜5)。しかし，実際の金属 表面の幾何学的輪郭を 3 次元的に把暒したり，その表 面突起の押しつふし遇程における挙動を解析すること は極めて困蜼である。

従来，このような押しつふし遇程の解析では，一般 に2 次元のくさび型突起モデルを用いて，すべり線場 法を用いた突起部分の変形挙動の解析 バルク（基地の部分）が共に変形する状態までの解析 をめざした大変形弾塑性有限要素法などの手法により, 多くの知見が得られてきだへ121。一方，実験的には， 巨䘽的な投影器などによる形状の拡大観察や，面内ひ ずみの観察を主とした格子法やモアレ法1日）などの光 学的手法に基づ潘定例がられる。しかし、これら の方法は，前もって格子等を武料に貼り付け，各圧箱 段階ごとに試料を装置から取り出し，その変形格子を

\footnotetext{
* 原稿受付 平成元年9月18日，1989年度精密工学 会春季大会学術譜演会 (平成元年3月24日) にて 発表

x* 正会只 姬路工業大学（姬路市書写2167）

x*x 正会只神戸䌘銅所（株）（神戸市中央区脇浜町 1-3-18; 前 姬路工業大学大学院)
}

観察することにより，突起形状を测定しなくてはなら ない.

本報告では, 多数開口ホログラフィ干渉法131 〜 15) による粗さ突起モテルの, 押しつふし遇程における形 状の変形挙動の測定について述べる. 本手法では, 非 接触で高感度に変位分布の測定が連続的に可能なため に，押しつふし遇程における粗さモデルの変形がイン プロセスで計測できる特徽を持つ.また，本手法によ り材料の弾性領域と塑性領域に対する材料流れに起因 した変形の密度分布の様子を, 干涉じまとして観察で きた。なお実駼には，粗さモデルとして，主に突起部 分の変形をできるだけ正確に観察するための円すい柱 型試料と, 突起部分とバルクの変形を共に観察するた めの台付き円すい柱型試料を用いた。

\section{2. 淵定原理}

ホログラフィ干涉法では, 物体の変形前後の二つの 光波間で干涉じまを作ることにより, 波長オーダの感 度で変位分布の测定ができる ${ }^{16)}$. 図 1 に示すように， 物体の一点 $\mathrm{P} か ゙ \mathrm{P}$ 'に変位したときの変位べクトルと しま次数 n（位相変化）には次式の関係がある.

$$
\mathbf{u}(\mathbf{S i}-\mathbf{S o})=\mathrm{n} \lambda
$$

ここで, Si は P 点を照明するレーザ光の単位ベクト 


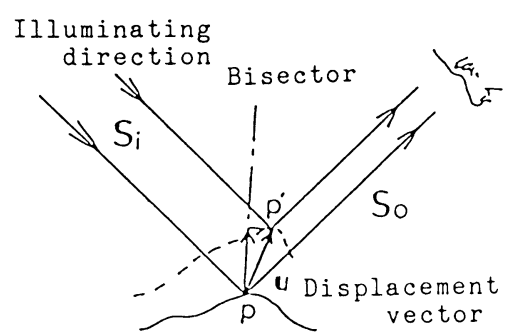

object

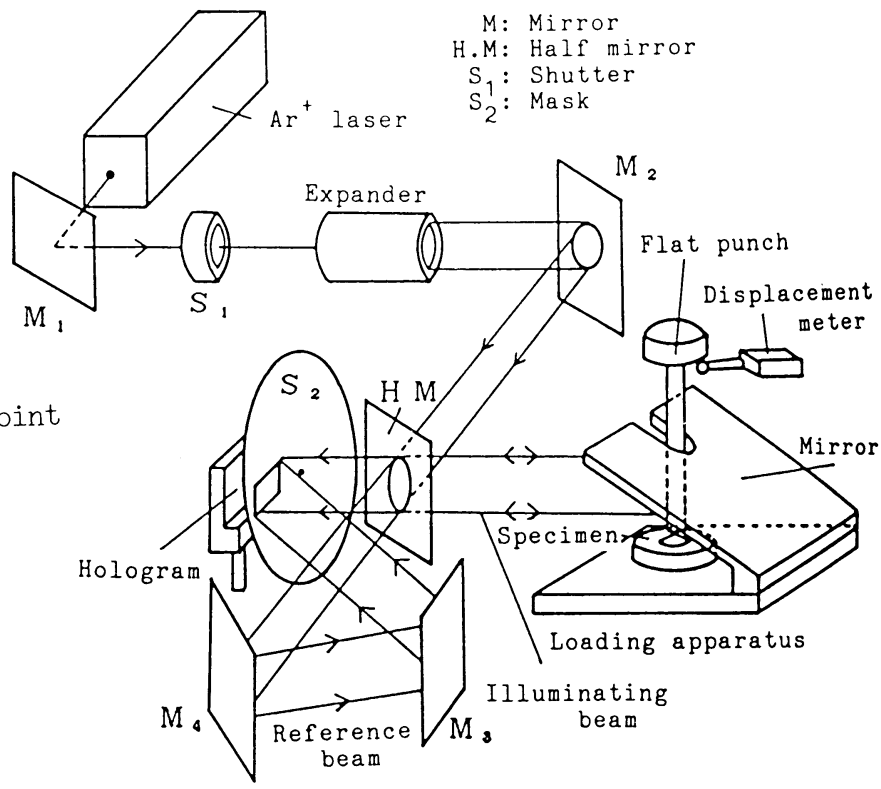

Fig.3 Schematic system of the experimental setup

このようにして得られたホログラム再生による物体上 の干涉じまの動きより，物体の変形挙動を観察するこ とができる。

\section{3. 实}

粗さモデル試験片の，押しつぶしによる形状の変形 挙動を観察するために，図 3 に示すような光学配置を

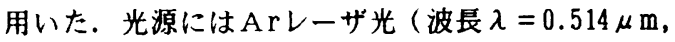
出力約 $100 \mathrm{~mW}$ ) を用いており，レーザ光はエキスパ ンタにより直径 $80 \mathrm{~m} \mathrm{~m}$ の平行光となり,ハーフミラ 一により，一方は物体照明光に，他方は参照光として 乾板上に照射される，なお乾板の前には，開口位置を 決定するための回転板マスクを配置する，物体照明光 は，45。傾斜したミラーにより，粗さモデル試料に 真上から入射し，観察方向も同じく真上とした。した かって，ホログラムで記録される干涉じまは，粗さモ デル突起の荷重方向の変形の $\lambda / 2(0.26 \mu \mathrm{m})$ こと の等変位成分を表す。

加压スタンプはS $45 \mathrm{C}$ 材で, 直径 $5 \mathrm{~mm}, 6.4$ $\mathrm{mm}, 9 \mathrm{~mm}$ を彆作し，スタンプ部は焼入れ後，研的

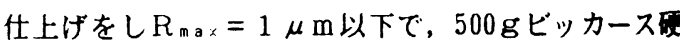
さ290であった。これらのスタンプは，スタンプ接 触面近傍での粗さモデルの変形挙動をできるだけ筑察 するために，段階的に取り替えて使用した。加圧は， 変位計により圧下量を測定しながら, 油圧アクチュエ 

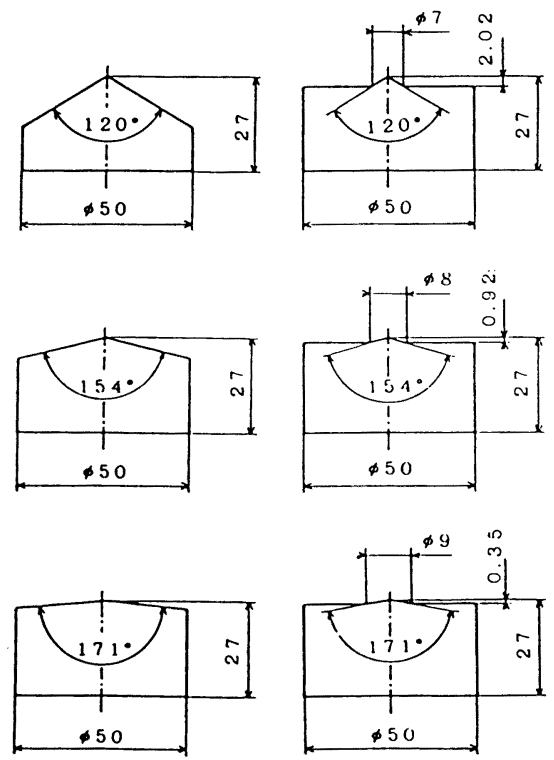

(a) Conical cylinder type

(b) Cone type with base

Fig.4 Size of asperity model

\section{一タにより静的に行った。}

柤さモデルは， 3 次元の円すい柱型突起モデルで， 図4にその寸法形状を示す，突起部分の変形のみをて きるたけ正確に観察するための試料（円すい柱型） と, 突起部分とバルクの変形を共に観察するための武 料（台付き円すい柱型）を準備した。突起の頂角は $120^{\circ} ， 154^{\circ} ， 171^{\circ}$ を選び，材料には工業 用純アルミニウムを用い，旋削後 $270^{\circ} \mathrm{C} て ゙ 1 \mathrm{~h}$ 焼き なまし，200g ピッカース硬さ 27 とした。

図 5 に突起の押しつふしによる形状变化と，その実 梌手順について示す。はじめに, 突起粗さモデルを観 察したい初期圧䨂量 X0まで押しつぶすと，スタンプ の接触面半径は $\mathrm{r}_{\mathrm{B}}$ となり, 突起頂上部で押しつぶさ れた体積は側面への盛り上がり量となる。この状態で 1 回目のホログラフィ記録を行う. 次に, 钽小変位量 $\Delta X$ を加えると，側面に盛り上がった形状とほぼ相似 に，図中で里く治りつぶした量だけ微小変形が生じる. ここで 2 回目のホログラフィ記録を行うことにより, 初期圧縮量 Xo 近傍における変形挙動が観察できる. 以下，このように観察したい形状の初期圧縮量 Xo を 変えながら，このような 2 重露光法を絽り返すことに より, 各圧維量近傍に対する突起の変形挙動が観察で きる.なお，千渉じまは図中の変位成分 $u(r)$ が $\lambda$ ／ 2ごとに現れる.

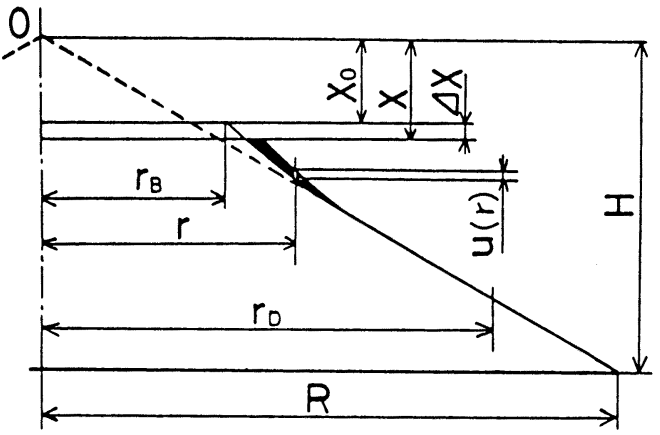

$X$ : Initial compression of asperity

$\mathrm{X}^{\mathrm{O}}$ : Compression of asperity

$\Delta \mathrm{X}$ : Small compression of asperity for recording holography $r$ : Distance from center

$U(r)$ : Small deformation at distance $r$

$r_{D}$ : Maximum radius of a plastically

deformed asperity by holography

$r_{B}$ : Radius of contact area

$R^{B}$ : Initial radius of asperity

$\mathrm{H}$ : Initial asperity height

Fig.5 Deformed asperity and nomenclature

\section{4. 実雅結果と考寀}

\section{1 突起形状の変形举動の润定}

ホログラフィ干渉法による突起の变形挙動の桷定例 を図6に示す. 図中の写真は円すい柱型の突起頂角 $120^{\circ}$ のモデルで, 初期圧縮量 X $0=1.475 \mathrm{~mm}$ において, 钽小変位量 $\Delta \mathrm{X}=4.5 \mu \mathrm{m}$ に対する変位 分布を示している. なお干涉じまは $0.26 \mu \mathrm{m}$ の等 変位線である. 図中の縦軸は荷重方向の変位量で, 横 軸は中心からの距都 $\mathrm{r}$ を示している. スタンプ近傍で 变位曲線の傾きが急になっていることより, 変形は主 としてスタンプ近傍で起こっていることがわかる.

突起頂角 $154^{\circ}$ の台付き円すい柱型粗さモテルに おける突起の变形举動の測定結果を図 7 に示す。実駼 に際しては，変形が主にスタンプと突起の接触部近傍

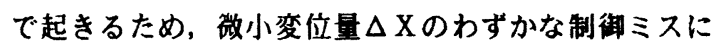
より干涉じまはすぐに密となり計数が困䩿となる。そ のため, 各圧縮率近傍で微小変位量 $\Delta \mathrm{X}$ (約 $3 \mu \mathrm{m})$ を注意深く与えて数こまずつ記録し，その平均值より 変形量を求めた。 上から圧縮事か， $0.29 ， 0.38$, 0.54 における微小変位量 $\Delta X$ に対する変形挙動を 示す，縋軸は各点の变位量 $\mathrm{u}$ を钽小变位量 $\Delta \mathrm{X}$ により 無次元化し, 横軸は突起中心から干涉じまの位置まで 


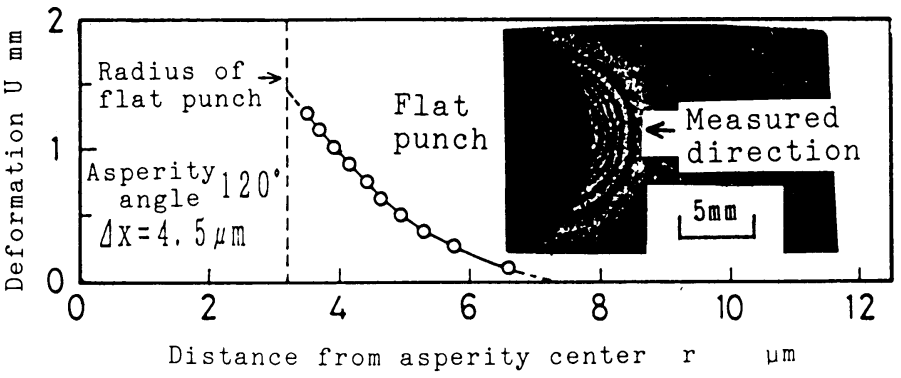

Fig.6 Deformation of an asperity model by holographic interference fringe
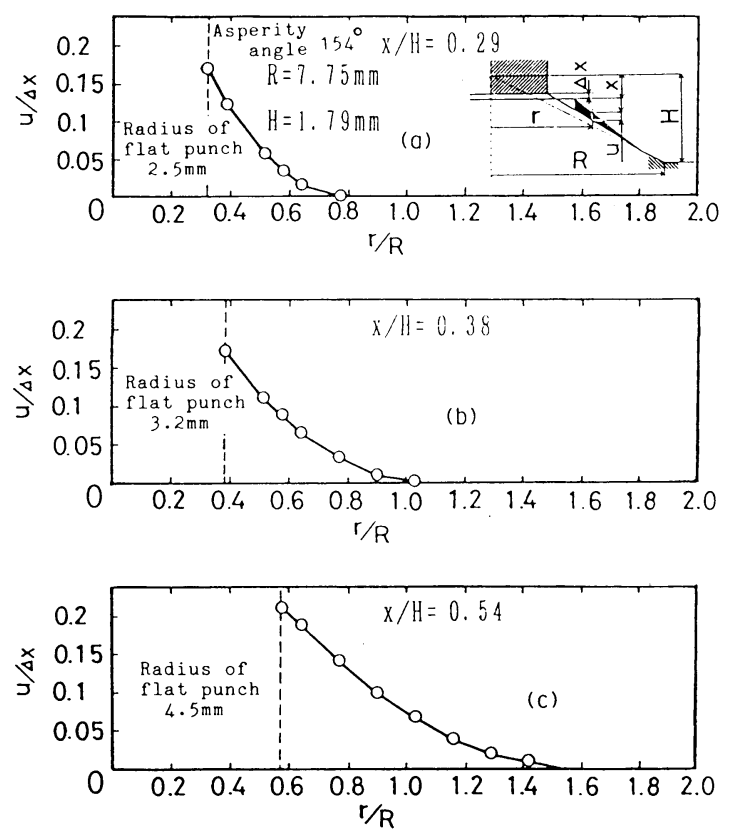

Fig.7 Deformation behavior of asperity with increase of compression

の距離 $\mathrm{r}$ を，突起すその径 $\mathrm{R} て ゙$ 無次元化している，図 より, 变形は突起頂上部付近で局部的に起こり始める (a). 変形が突起すその径を越え出すと $(\mathrm{r} / \mathrm{R}=$ 1.0），しだいに緩やかとなって，すそのへ広がっ ていくことがわかる(b). なお変形が突起部周辺のバ ルク上に及んでも,バルクには急な隆起などは見られ ず,むしろなだらかに変形は進行している(c).なお， 頂角が $120^{\circ} ， 170^{\circ}$ の突起モデルにおいても, ほぼ同じような結果が得られた。

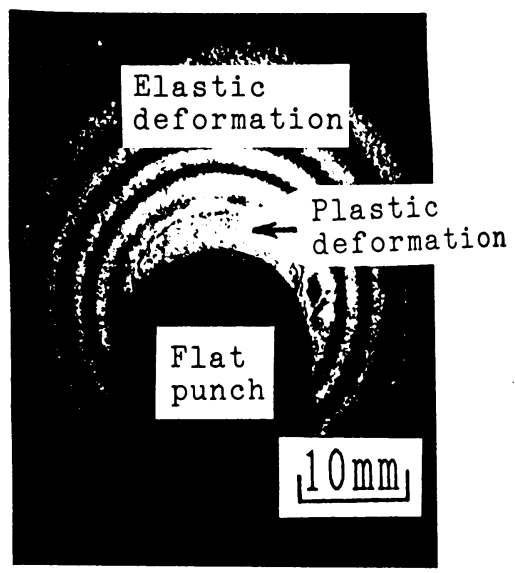

Conical cylinder type Asperity angle $120^{\circ}$ $\Delta \mathrm{X}=100 \mu \mathrm{m}$

Fig. 8 Distinction between elastic deformation and plastic deformation by holographic interference fringes

\section{2 突起の望性変形城の汧定}

ホログラフィ干涉法の感度で粗さモデルの変形を捕 らえた場合，微小变位量 $\Delta \mathrm{x}$ を大きくとると図8に示 すような干渉じまが現れる.スタンプ近傍では檑めて 密な干渉じまが存在し，その外側に疎な干涉じまが存 在している，密な干涉じまは，ほほ同心円をなしてい るが，よく見ると細かい凹凸があり，材料内部に活琴 な流れがあったことが推察される。これらの干涉じま の密度分布の違いは，一般に金属の応力ひすみ線で， その勾配（ $0.2 \%$ 耐力）により材料の弾性変形と望 性変形を区别しているのに相当すると考えられる。 こで，このようなしまの密度の不連䌇な境界が，材林 の弹性と塑性の境界に相当すると考え，中心からこの 境界までの半径を，ホログラフィ干涉法により㛟出さ れる塑性域半径の最外径とした。

異なる頂角をもつ円すい柱型粗さモデルにおける， 圧縮量Xに対する突起の形状变化について図 9 に示す， 図中に，ホログラフィ干涉じまから求めた塑性城の

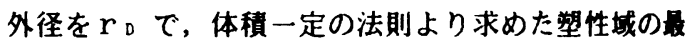
外径を $\mathrm{r}$ 、で示す．このr、は，圧縮量Xにより排除さ れた円すいの体積が侀面に盛り上がるとして，接篮面 の長さ $2 \mathrm{r}_{\mathrm{B}}$ が，盛り上がりを直線近似した何面の長 さに等しくなると仮定して算出した，rs は同拣な実 臨について, 万能投影器により圧縮中の突起形状を逐 次測定して求めた接触面半径 $\mathrm{r}_{\mathrm{B}}$ をもとに，図10に 


\begin{tabular}{c|c|c|c|c}
\hline $\begin{array}{c}\text { Asperity } \\
\text { angle }\end{array}$ & $\begin{array}{c}\text { Holography } \\
r_{D}\end{array}$ & $\begin{array}{c}\text { Volume } \\
\text { constant law } \\
r_{V}\end{array}$ & $\begin{array}{c}\text { slip-line } \\
\text { fields } \\
r_{S}\end{array}$ & $\begin{array}{c}\text { Radius of } \\
\text { contact area } \\
r_{B}\end{array}$ \\
\hline $120^{\circ}$ & $4.95 \mathrm{X}$ & $3.76 \mathrm{X}$ & $5.54 \mathrm{X}$ & $2.09 \mathrm{x}$ \\
$154^{\circ}$ & $13.4 \mathrm{X}$ & $9.96 \mathrm{X}$ & $14.7 \mathrm{X}$ & $5.12 \mathrm{X}$ \\
$171^{\circ}$ & $39.3 \mathrm{X}$ & $36.2 \mathrm{X}$ & $43.1 \mathrm{X}$ & $15.9 \mathrm{X}$ \\
\hline
\end{tabular}

Fig.9 Influence of asperity angle on deformation of asperity

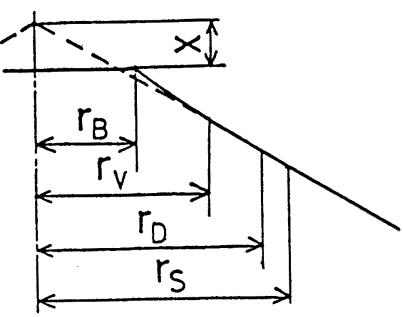

$X$ : Compression of asperity

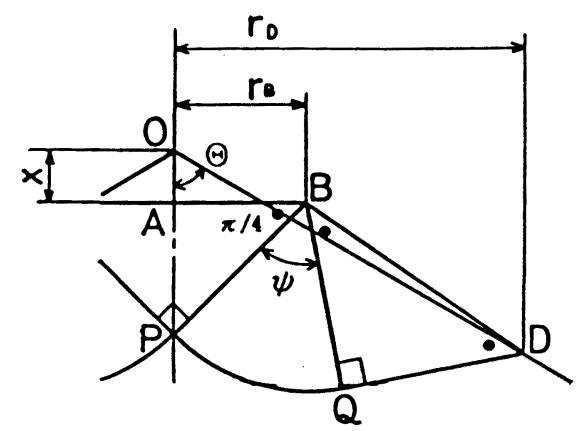

Fig.10 Slip-line fields of an asperity model subjected to pressure by flat punch

示すようなHillの 2 次元すべり線図 ${ }^{171}$ を描いて求め た塑性域の最外径である，なお，すべり線は直線と円 弧からなる有心扇形であり，以下の原則をもとに求め ている.

1)せん断すべりは表面と $45^{\circ}$ の角度をなす.

2)境界条件が連䌇性を欠く所では，有心扇形場となる。 突起頂角 $120^{\circ} ， 154^{\circ} ， 171^{\bullet}$ について, 压暙量 Xに対する形状変化を表すパラメー夕は，いず れも强い相関があり，図 9 に示すような実駼式が得ら れた。この回㷌直線における決定係数は，ともにほほ 0.99であった。

図 11 に, 突起頂角 $154^{\circ}$ の台付き円すい型の粗 さモデルの押しつふしにおける塑性域半径と圧縮量と つ関係を示す，図には，ホログラフィ干涉法により求 めた塑性域半径 roと, 参考にHill の2 次元すべり紻 因より求めた塑性娀半径ｒｓを示している，図中の絴 润は, 望性娀半径を突起すその径 Rで無次元化し，横 洞は压編量Xを突起高さHで無次元化してある．变形 が突起部分（ $r_{0}, r_{s} / R$ が 1 以内）で起こっている 易合には，塑性変形域は圧緢量に対して，ほぼ比例的 に変化したので，図中には，その実験式を実線（ホロ ダラフィ干涉法による值）と一点鎖線（すべり線場に

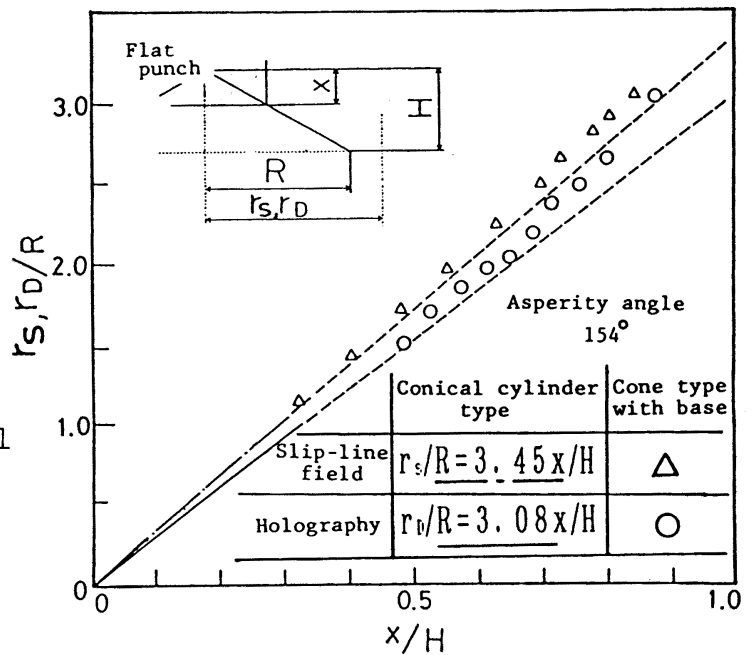

Fig.11 Relation between maximum radius of plastic deformation area and compression of asperity

よる值) で示す、図より，変形がバルク部分におよふ と，しだいに圧寉量 $\mathrm{x}$ に対する望性変形域 $\mathrm{r}_{\mathrm{D}} ， \mathrm{r}_{\mathrm{s}}$ は 直線からはずれて緩やかに周辺に広がっていくことが わかる. この㑯向は頂角が $120^{\circ}$ の埸合には, より 大きく, 又 $171^{\circ}$ の埸合は小さかった.

\section{5.まと め}

ホログラフィ干涉法を用いて，粗さモデルの変形举 動を解析する方法について娭討を行った，以下に本手 法によって得られた主な結果を示す.

（1）ホログラフィ干涉法の测定感度を用いると，千 涉じまの密度分布の相遣により，筒単に突起の変 形域を定量化できる.

（2）突起の押しつふし変形は, 始め突起の頂上部付 
近で局部的に起こり，突起すそのに塑性域が及ふ までは圧縮量に比例して進むが，バルク上では楥 やかに周辺に広がる。

（3）ホログラフィ干渉法によって求めた压縮量と塑 性変形域との関係は，すべり線場による解と定性 的に一致する.

おわりに, 本実験に協力いただいた本学卒研生, 蔽 井裕寿君, 山田浩平君に感䪭します.

\section{私考文献}

1）渻添 正: 表面あらさと面の接触機槽について, 洞滑，13，(1968） 101.

2）久門徸正：固体仕上げ面間の接触機構，日本機械 学会論文集, 35,(1969) 861 .

3）大矢根守哉：塑性加工による素材の表面あらさの 变化, 潤滑, 19,(1974) 155 .

4）塚田忠夫：表面あらさと接触変形問題，閵消，19 (1974) 135.

5) T. Wanheim: Friction at High Normal Pressures, Wear, 25, (1973) 225.

6）太田友弥, 進藤明夫, 福田秀和, 杉本和雄: 用体 平面によるくさびの押しつぶれ，日本機械学会論 文集, 23,(1957) 242 .

7）進藤明夫：くさびの押しつぶれの一般的考察, 日 本機械学会論文集. 27,(1961) 447 .

8）牧野内昭武，池 治, L.F.Ciupik：バルクの塑性 変形を考虑した表面の平滑化機槽（第 1 報, 無摩 徖での3 連くさび形突起押しつぶしのF EM解析) 第36回塑加連撞論，（1985）5.

9）牧野内昭武，池 治，林 第: バルクの塑性变形 を考慮した表面の平滑化機構（第2 報，表面突起
の押しつふしにおける素材拘束条件の影专)，昭 和 61 年度塑性加工春季陆演会，（1986）127。

10）古関伸裕, 住吉 宏, 村川正夫, 牧野内昭武, 洗 治：バルクの塑性变形を考虑した表面の平滑化 侢（第 3 報，モアレ法を用いた実駼と有限要素法 による計算結果の比較)，第37回塑加連啸論， (1986) 443.

11）池 治，牧野内昭武，木村美喜雄：バルクの塑件 変形を考慮した表面の平滑化機槽（第 4 報，連视 くさび形突起の無摩擦押しつふしに及ほすす試験片 の加工硬化特性と拘束条件の影蚃)，昭和 62 年 度塑性加工春季講演会，（1987） 269.

12）池 治，牧野内昭武，木村美喜雄：バルクの塑性 变形を考虑した表面の平滑化機槽（第5 報，表面 凹凸のくさび角の影響 )，第38回塑加連講論， (1987) 657.

13) S.Kakuna i, K.Iwata, R.Nagata, M.Hasegawa: Multiple Aperture Holographic Interferonetr. and its Application to the Measurement of Plant Movement, Appl.0pt., 25,(1986) 1638.

14）格内 敏, 渡遗嘉郎：軸方向圧縮円柱の側面変形 のホログラフィ干涉法による解析，精密機㳦,47, $3,(1981) 265$.

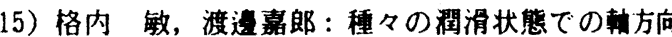
圧䈹円柱の側面変形のホログラフィ干涉法による 観察, 精密機械, 48,3,(1982) 299.

16）例えば C.H.Vest: Holographic Interferometry John Wiley and Sons., New York (1979) pp.68.

17）例え估 W.Johns on and P.B.Mellor著（清田堅吉 山田義昭, 葉山益次郎 訳)：塑性加工学, 培后 館 (1965) pp. 129 . 